\title{
Norovirus Infection among Children Under 5 Years of Age In Niger-Delta Zone, Nigeria
}

\author{
Oghomwen F. Osazuwa', Rachel Okojie ${ }^{2}$, Frederick O. Akinbo'
}

${ }^{1}$ Department of Medical Laboratory Sciences, University of Benin, Benin City, Edo State, Nigeria.

${ }^{2}$ Department of Microbiology, University of Benin, Benin City. Edo State, Nigeria

*Correspondence should be addressed to Oghomwen Osazuwa: oszmarventonic@gmail.com

Received 07 July 2019; Revised o8 August 2019; Accepted 11 August 2019

(C) 2019 Osazuwa et al. Licensee Pan African Journal of Life Sciences. This is an Open Access article distributed under the terms of the Creative commons Attribution License (https://creativecommons.org/licenses/BY/4.0), which permits unrestricted use, distribution, and reproduction in any medium, provided the original work is properly cited.

Background: Norovirus is now recognized as a major cause of gastroenteritis among children worldwide. This study aimed to determine the prevalence of Norovirus infection among children that are less than five years of age in Niger-Delta zone, Nigeria.

Methods: A total of 263 subjects consisted of 163 children with diarrhea attending Paediatric clinics at the Central Hospital, Warri and Federal Medical Center, Yenagoa as well as 100 aged- and sex-matched healthy individuals that served as controls were recruited for this study. Demographic information was obtained through the aid of a well-structured questionnaires. Norovirus was detected by using a rapid lateral flow immunochromatographic assay kit (Biopanda reagents, Belfast, United Kingdom).

Results: The overall prevalence of Norovirus infection was $15.3 \%$. The prevalence of Norovirus infection was significantly higher in Delta State than in Bayelsa State $(22.9 \%$ vs. 6.7\%; OR= 3.6615; 95\% CI = 1.378, 9.725; $\mathrm{P}=0.0092)$. Children that are less than 5 years of age attending day care centers are greatly affected by Norovirus infection $(\mathrm{P}=0.0044)$. Also, poor hand hygiene practice was also a significant risk factor for Norovirus infection among study subjects $(\mathrm{P}=0.0036)$. Furthermore, secretors were found to have a 1 to 334 fold increased risk of acquiring Norovirus infection in Delta State than in Bayelsa State (OR=19.28, 95\% C.I, 1.1102, 334.68, $\mathrm{P}=0.0422)$.

Conclusion: The need for routine screening for Norovirus infection among children with diarrhea is advocated. Data from this study as well suggests that genetic and environmental factors play a role in Norovirus infection.

Keywords: Bayelsa and Delta States, Norovirus, Secretor status, Children under 5 years 


\section{1.o INTRODUCTION}

Viral gastroenteritis is a major threat with high morbidity and mortality rates, especially in children, elderly and immuno-compromised individuals in developed and developing countries [1]. Noroviruses (NoV) cause an estimated 1.1 million hospitalizations and up to 218,000 deaths among children that are less than 5 years of age annually [1]. NoV has been reported to be responsible for the death of 200,000 children in developing countries every year [2]. Following the introduction of Rotavirus vaccines, Human Noroviruses are now currently hypothesized to be the leading cause of epidemic acute non-bacterial gastroenteritis worldwide [3]. $\mathrm{NoV}$ is a genus in the family Caliciviridae and is an icosahedral virus $\sim 38 \mathrm{~nm}$ large with an $\sim 7.5 \mathrm{~kb}$ single- stranded, positive-sense RNA genome that encodes three large open reading frames (ORF 1, ORF 2 and ORF 3). ORF1 encodes the replicate polyprotein, while ORF2 and ORF3 encode the major and minor capsid proteins, respectively [4]. NoV exhibits high genetic diversity and can be divided into six genogroups (GI, GII, GIII, GIV, GV, GVI) [5].

NoV is by far the most frequent pathogen in epidemic diarrhea in both developing and industrialized countries, with outbreaks frequently occurring in closed settings such as hospitals and day-care centers [6]. Moreover, the high stability and infectivity of the virus makes it a common cause of food and waterborne gastroenteritis [6]. Despite these facts, there are no vaccines or therapeutic treatments available for this disease [6]. Additionally, little is known about the transmission pathway of the virus, and the measures that should be taken in order to prevent contamination of the environment are not in place. These un-clarities are partly due to the complexity of this virus as there are often several strains circulating due to the virus genomic recombination and point mutations. The strains have each of their own intrinsic properties that are related to the differences in severity, transmission pathways, and receptor specificities in the human host [7].

Certain studies have associated NoV susceptibility with secretor status- defined by the presence of an $\alpha(1,2)$ linked fucose on histo-blood group antigens (HBGAs), which is determined by the FUT2 gene [8]. Individual carrying $>1$ functional FUT2 allele, and thus expressing $\alpha$ $(1,2)$ fucosyltransferase 2 (FucT-II), are secretor positive (termed secretors) and can express the blood group A and $B$ antigens as well as the H-type 1 and Lewis b (Leb) antigens on mucosa and in secretions. In contrast, people lacking FucT-II (non-secretors) have been found to be highly protected against infections from several NoV gen- otypes, including the common GII.4, as well as the Norwalk virus prototype strain (GI.1) [9]. There is dearth of information on the association between secretor status and Norovirus infection among children that are less than 5 years of age with diarrhea in Delta and Bayelsa States, against this background, this study was conducted to determine the prevalence of $\mathrm{NoV}$ and its association with secretor status among children under-5years old with diarrhea in Delta and Bayelsa States, Nigeria.

\section{2.o METHODOLOGY}

\subsection{Study Area}

This cross-sectional study was carried out in two hospitals: the Central Hospital, Warri (Delta State) and the Federal Medical Centre, Yenagoa (Bayelsa State). Both hospitals are tertiary hospitals located in the NigerDelta region of Nigeria, which is the major hub for crude oil related business in the South-South Nigeria. Warri is an oil hub in Delta State, with a population of over 311,970 , while Yenagoa is the capital city of Bayelsa State with an estimated population of 266,008 [10].

\subsection{Study Population}

This study included children under the age of 5 suffering from diarrhea that were at the Paediatric Out-patient clinics, Special Care Baby Units, and the In-patient wards of the Central Hospital, Warri and Federal Medical Centre, Yenagoa. Children with at least three episodes of diarrhea with an onset of one day to seven days- were included in the study. Children whose parents or guardians consented to participate, who were within the ages of $0-5$ years were recruited in this study. The exclusion criteria included the refusal of the parents/ wards to give consent or when the child was on antiviral therapy. A structured questionnaire was administered to collect data bothering biodata, socio-demographics, and clinical symptoms from parents/caregivers of each subject before specimen collection. A total of 263 faecal specimens, consisting of 163(83 from Delta and 80 from Bayelsa States) children with diarrhea and 100 apparently healthy aged and sex matched as controls were analyzed for NoV. The protocol for this study was approved by the Ethics and Research Committees of the Ministry of Health of both Delta and Bayelsa States with reference numbers CHW/VOL14/30 and FMCY/REC/ $\mathrm{ECC} / 2017 / \mathrm{OC} / 046$ respectively.

\subsection{Screening for Norovirus}

NoV in stool specimens was qualitatively detected using a lateral flow immunochromatography test kit (Biopanda, Belfast, United Kingdom) following the manufacturer's instructions. Briefly, approximately $50 \mathrm{mg}$ or $50 \mu \mathrm{l}$ stool (solid or liquid) was dispensed into a specimen collection 
tube containing the extraction buffer. This was then shaken vigorously to mix the specimen and the extraction buffer. Test cassettes were opened gently and approximately 8oul of the extracted specimen were transferred to the test cassette. Results were read after $15 \mathrm{~min}$. The results of the test were reported as positive, negative or invalid accordingly.

\subsection{Secretor status}

This was determined using commercial test kits La and Lb antisera (Lorne Laboratories, Danehill Berkshire United Kingdom). Briefly, a 2-3\% of washed red blood cells was prepared while $30 \mu$ of the washed red cells and Lorne Lewis reagent was placed in a labeled test tube. This was then mixed thoroughly and incubated at room temperature for $15 \mathrm{~min}$. All tubes were centrifuged for 20 $\mathrm{sec}$ at 1000 relative centrifugal force. It was read macroscopically for agglutination. Secretor status were then interpreted following manufacturer's instructions, nonsecretors generated Le $\left(a^{+} b^{-}\right)$agglutination reaction, the secretors will generate the Le $\left(a^{-} b^{+}\right)$agglutination reaction.

\subsection{Statistical Analysis}

Data obtained were analyzed using Chi square (X2) test for frequency data and odd ratio analysis for potential risk factors. The statistical software used for all analyses was SPSS v. 16(IBM Computer Manufacturing Company, NY, USA).

\subsection{RESULTS}

The overall prevalence of Norovirus among children with diarrhea was $15.3 \%$, there was no Norovirus infection among the control subjects (Table 1).

Table 1. Prevalence of Norovirus among children in Delta and Bayelsa States

\begin{tabular}{lllll}
\hline States & $\begin{array}{l}\text { No of } \\
\text { Samples }\end{array}$ & $\begin{array}{l}\text { No. Infect- } \\
\text { ed (\%) }\end{array}$ & OR & p-value \\
\hline Delta & 83 & $19(22.9)$ & 3.6615 & \\
Bayelsa & 80 & $6(7.5)$ & & 0.0092 \\
Total & 163 & $25(15.3)$ & & \\
\hline
\end{tabular}

In this study, age associated with the prevalence of Norovirus infection only among participants in Bayelsa State $(\mathrm{P}<0.001)$ (Table 2). There was a significant difference in the infection of Norovirus between subjects from Delta and Bayelsa States (Delta 22.9 \% vs Bayelsa 7.5 \%; OR 3.6615; 95\% CI 1.378, 9.725; $\mathrm{P}=0.0092)$.
Table 2. Relationship between age and Norovirus infection among children in Delta and Bayelsa States

\begin{tabular}{lllllll}
\hline & \multicolumn{2}{c}{ Delta } & & \multicolumn{3}{c}{ Bayelsa } \\
\hline $\begin{array}{l}\text { Age } \\
\text { (Mnth) }\end{array}$ & $\begin{array}{l}\text { No. } \\
\text { Test- } \\
\text { ed }\end{array}$ & $\begin{array}{l}\text { No. } \\
\text { infected } \\
(\%)\end{array}$ & $\begin{array}{l}\text { p- } \\
\text { value }\end{array}$ & $\begin{array}{l}\text { No. } \\
\text { Tested }\end{array}$ & $\begin{array}{l}\text { No. } \\
\text { In- } \\
\text { fected } \\
(\%)\end{array}$ & $\begin{array}{l}\text { p- } \\
\text { value }\end{array}$ \\
$0-1$ & 38 & $8(21.1)$ & 0.253 & 46 & $\begin{array}{l}6 \\
(13.0)\end{array}$ & $<0.0$ \\
$2-3$ & 25 & $9(36.0)$ & & 25 & 0 & 01 \\
$4-5$ & 20 & $2(10.0)$ & 9 & 0 & \\
\hline
\end{tabular}

Generally, gender and type of toilet did not affect the prevalence of Norovirus among children under the age of 5 ( $\mathrm{P}>0.05)$. However, attendance at Day Care Centers significantly affected the prevalence of Norovirus infection $(\mathrm{OR}=0.2787 ; 95 \% \mathrm{CI} \quad 0.1157, \quad 0.6714 ; \mathrm{P}=$ 0.0044). In this study, secretor status significantly affect the prevalence of Norovirus infection in Delta State (OR 19.28, 95\%CI 1.1102, 334.68, $\mathrm{P}=0.0422$ ) but not among subjects in Bayelsa State (Table 3). NoV infection was significantly higher during the rainy season among participants in both Delta and Bayelsa States (Table 3).

\section{4.o DISCUSSION}

Norovirus (NoV) has been identified to constitute a key biological cause of gastroenteritis worldwide [11]. To the best of our knowledge, this is the first study to determine the prevalence of Norovirus in Delta and Bayelsa States, Nigeria. An overall prevalence of $15.3 \%$ Norovirus infection was observed among children with diarrhea in Bayelsa and Delta States, Nigeria. This prevalence is similar to $13.5 \%$ reported by Mans et al [12], in a multicenter study in fourteen different African countries. The prevalence observed in this study is higher than the $6.7 \%$ reported in North East, Nigeria [13], but less than the reported prevalence of $37.3 \%$ among children in Lagos [14] and $25.5 \%$ in a study at Ile-Ife, Osun State [15]. The prevalence of Norovirus in this study when compared to other African countries was less than $29.6 \%$ obtained in Cameroon [16], but higher than $11.3 \%$ and $11.8 \%$ in community based studies in Malawi [17] and Tanzania [18] respectively. This observation suggests that Norovirus infection is a significant cause of diarrhea in Delta and Bayelsa States. The difference in Norovirus infection in this study and that of other studies might be due to differences in hand washing practices, food and water sources, sanitization practices, climatic factors, environmental/household characteristics.

Norovirus prevalence between these two close States with similar climatic, environmental and geographical conditions is unclear. Norovirus infection is higher in 
Table 3. Association between Norovirus infection and risk factors among children less than 5 years children in Delta and Bayelsa

\begin{tabular}{|c|c|c|c|c|c|}
\hline & Characteristic & No. Tested & $\begin{array}{l}\text { No. Infected } \\
(\%)\end{array}$ & $\mathbf{O R}$ & p-value \\
\hline \multirow[t]{2}{*}{ Gender } & Males & 98 & $17(17.3)$ & 0.709 & 0.453 \\
\hline & Females & 65 & $8(12.3)$ & & \\
\hline \multirow[t]{3}{*}{ Types of toilet in use } & Water Cistern & 69 & $7(16.7)$ & & \\
\hline & Pit Laterine & 88 & $17(19.3)$ & & 0.3927 \\
\hline & Open (bush) Defecation & 06 & $1(16.7)$ & & \\
\hline \multirow[t]{2}{*}{ Hand washing with soap after defecation } & Yes & 69 & $3(4.3)$ & & \\
\hline & No & 94 & $22(23.0)$ & & \\
\hline \multirow[t]{2}{*}{ Attendance at Day Care Centre } & Yes & 54 & $16(29.6)$ & 0.2787 & 0.004 \\
\hline & No & 109 & $9(8.3)$ & & \\
\hline \multirow[t]{2}{*}{ Secretor status Delta } & Secretor & 62 & $19(30.6)$ & 19.280 & 0.042 \\
\hline & Non secretor & 21 & 0 & & \\
\hline \multirow[t]{2}{*}{ Secretor status Bayelsa } & Secretor & 71 & $4(5.6)$ & 0.210 & 0.1003 \\
\hline & Non secretor & 9 & $2(22.2)$ & & \\
\hline \multirow[t]{2}{*}{ Season (Delta) } & Rain & 53 & $18(33.9)$ & & 0.0012 \\
\hline & Dry & 30 & $1(3.3)$ & & \\
\hline \multirow[t]{2}{*}{ Season (Bayelsa) } & Rain & 49 & $3(6.1)$ & & 0.556 \\
\hline & Dry & 31 & $3(9.7)$ & & \\
\hline
\end{tabular}

early childhood with children $<2$ years old more likely to be infected; this finding has also been confirmed in studies done in North-eastern, Nigeria [13], and in Vhembe district, South Africa [19].

Gender did not significantly associate with Norovirus infection in this study (OR= 0.7095, 95\% CI 0.2893 , 1.7937 $\mathrm{P}=0.4533)$. This finding is in tandem with that of Babalola and colleagues [20]. This suggests that gender may have no role in shaping Norovirus dynamics in the areas under this study. Urbanization and work regulations make mothers and caregivers source for day care centers for their children/wards. Thus, inappropriate hand cleanliness [21] and close contact with infected persons at these Centers must have accounted for the significant $\mathrm{NoV}$ infection recorded in this study at these locations [22, 23]. Hypothesis has been drawn from some proof of concept study that secretors are more likely to be Norovirus positive while non-secretors are highly protected from infections with several Norovirus genotypes [24]. In this study, secretor status affected strongly the prevalence of NoV in Delta State $(\mathrm{P}=0.0422)$. Though a previous study has reported a secretor independent Norovirus outbreak in Sweden [25]; the reason for Norovirus being more commonly detected among secretors in Delta State than in Bayelsa State is unclear.

This study shows that improper hygiene practice is a significant risk factor for NoV infection. Caregivers and parents should therefore institute proper environmental cleaningness and hand washing practice most especially for their wards after defecation. Government and nongovernmental organizations should as well invest in WASH facilities development in the Niger-Delta region.

\section{Acknowledgements}

Authors are grateful to the Parents/guardians for consenting to their children/wards participation. The Management of Federal Medical Centre, Yenagoa and Ministry of Health, Central Hospital Management Board, 
Warri are appreciated for their support. Mike Brambaifa, Ogboru D.O. and Dr Mayuku of Paediatrics Department of FMC, Yenagoa and Central Hospital, Warri are appreciated for assisting with recruitment and sampling .

\section{Conflict of interest}

The authors declare that they have no conflicts of interest.

\section{Authors Contribution}

FOA conceptualized the study, performed data collection, sample analysis, statistical analysis and drafted the manuscript. FOA, RO, NOE, carried out study design, provided study materials, validate result and revised manuscript . All authors approved the final manuscript.

\section{References}

1. Cotten M, Petrova V, Phan M V, Rabaa MA, Watson SJ, Ong SZ.. Deep sequencing of norovirus genomes defines evolutionary patterns in an urban tropical setting. Journal of Virology. 2014; 88: 11056-11069.

2. deGraaf M, van Beek J, Koopmans MP. . Human norovirus transmission and evolution in a changing world. National Review Microbiology. 2016; 14: 421-433.

3. Payne DC, Vinje J, SzilagyiPG,Edwars KM, Staat AM, Weiberg GA. Norovirus and medically attended gastroenteritis in US children. New England Journal of Medicine 2013; 368:1121-1130

4. Lindesmith LC, Costantini V, Swanstrom J, Debbink K, Donaldson EF, Vinje $\mathrm{J}$ et al. Emergence of a norovirus GII.4 strain correlates with changes in evolving blockade epitopes. Journal of Virology 2013; 87: 2803-2813.

5. Kroneman A, Vennema H, Deforche K, Avoort H, Penaranda S, ObersteMS et al. An automated genotyping tool for enteroviruses and noroviruses. Journal of Clinical Virology 2011; 51: 121-125.

6. Vinje J. Advances in laboratory methods for detection and typing of norovirus. Journal of Clinical Microbiology. 2015; 53: $373-381$.

7. Verhoef L, Hewitt J, Barclay L, Ahmed S M, Lake R, Hall AJ et al. Norovirus genotype profiles associated with foodborne transmission, 1999-2012. Emerging Infectious Diseases 2015; 21: 592-599.

8. Miura T, Sano D, Suenaga A, Yoshimura T, Fuzawa M, Nakagomi $\mathrm{T}$ et al. Histo-blood group antigen-like substances of human enteric bacteria as specific adsorbents for human noroviruses. Journal of Virology 2013;87:9441-9451.

9. Liu P, Wang X, Lee JC, Teunis P, Hu S, Paradise HT et al. Genetic susceptibility to norovirus GII.3 and GII.4 infections in Chinese pediatric diarrheal disease. The Pediatric infect Disease Journal 2014; 33:305-309.

10. National Population commission . National Population Census, 2006. National population commission, Abuja 2006, Nigeria.

11. Ahmed SM, Hall AJ, Robinson, AE, Verhoef L, Premkumar P, Parashar UD, Koopmans, $M$ and Lopman, BA. Gl;obal prevalence of Norovirus in cases of gastroenteritis: a systematic review and meta-analysis. Lancet Infectious Disease 2014; 14 (8): 725-730.
12. Mans J, Armah GE, Steele AD, Taylor MB. Norovirus epidemiology in Africa: a review. PLoS One 2016; 11 (4):eo146280.

13. Oyinloye, SO, Aminu M, EllaEE, JatauED.The prevalence and predisposing factors of norovirus and astrovirus infection among diarrheic children in north east, Nigeria. Journal of Public Health Epidemiology. 2016; 8: 204-210.

14. Ayolabi CI, Ojo DA, Armah GE, Akpan I, Mafiana CF. Detection and partial characterization of Norovirus among children with acute gastroenteritis in Lagos, Nigeria. Int J Med Medical Sci 2010;2: 216-221

15. Japhet OM, Adesina AO, Famurewa O, SvenssonL, NordgrenJ. Molecular epidemiology of rotavirus and norovirus in Ile-Ife, Nigeria: high prevalence of G12P[8] rotavirus strains and detection of a rare norovirus genotype. J Med Virol2012;84:1489-1496.

16. Ayukekbong J, Lindh M, Nenonen N, Tah F, Nkuo-Akenji T, Bergström T. Enteric viruses in healthy children in Cameroon: viral load and genotyping of norovirus strains. J Med Virol2011;83:2135-2142.

17. Trainor E, Lopman B, Iturriza-GomaraM, Dove W, Ngwira B, NakagomiOet al. Detection and molecular characterisation of noroviruses in hospitalised children in Malawi, 1997 -2007. J Med Virol2013;85:1299-306

18. Elfving K, Andersson M, Msellem M I. Real-time PCR threshold cycle cutoffs help to identify agents causing acute childhood diarrhea in Zanzibar. J Clin Micro 2014; 52 (3):916-923.

19. Kabue JP, Meader E, Hunter PR, PotgieterN. Norovirus prevalence and estimated viral load in symptomatic and asymptomatic children from rural communities of Vhembe district, South Africa. J Clin Virol 2016; 84: 12-18

20. Babalola MO, OdaiboGN, Olaleye DO, and Alonge AO. British journal of medicine and Medical research 2015; 9(8): 1-9

21. Lyman W, Walsh J, Kotch J, Weber D, Gunn E, Vinje J. Prospective study of etiologic agents of acute gastroenteritis outbreaks in child care center. J Pediatr 2009;154:253-257.

22. HeijneJC, Teunis P, Morroy G, Wijkmans C, Oostveen $\mathrm{S}$, Duizer T. Enhanced Hygiene Measures and Norovirus Transmission during an Outbreak. Emerg Infect Dis 2009; 15: 24-30.

23. Moore MD, GoulterRM, JaykusL. Human Norovirus as a Foodborne Pathogen: Challenges and Developments. Ann Rev FoodSci Tech 2015; 6: 411433 .

24. Bucardo F, Kindberg E, Paniagua M, Grahn A, Larson G, Vildevall $\mathrm{M}$ et al. Genetic susceptibility to symptomatic norovirus infection in Nicaragua. J Med Virol 2009; 81:728 $-735$

25. Nordgren J, Kindberg E, Lindgren PE, Matussek A, Svensson L. Norovirus Gastroenteritis Outbreak with a Secretorindependent Susceptibility Pattern, Sweden.Emerg Infect Dis 2010; $16: 81-87$

26. Kabue JP, Meader E, Hunter PR, PotgieterN. Norovirus 
prevalence and estimated viral load in symptomatic and asymptomatic children from rural communities of Vhembe district, South Africa. J Clin Virol 2016; 84: 12-18

27. Babalola MO, OdaiboGN, Olaleye DO, and Alonge AO. British journal of medicine and Medical research 2015; 9(8): 19

28. Lyman W, Walsh J, Kotch J, Weber D, Gunn E, Vinje J. Prospective study of etiologic agents of acute gastroenteritis

outbreaks in child care center. J Pediatr 2009;154:253257.

29. HeijneJC, Teunis P, Morroy G, Wijkmans C, Oostveen S, Duizer T. Enhanced Hygiene Measures and Norovirus Transmission during an Outbreak. Emerg Infect Dis 2009; 15: 24-30.
30. Moore MD, GoulterRM, JaykusL. Human Norovirus as a Foodborne Pathogen: Challenges and Developments. Ann Rev FoodSci Tech 2015; 6: 411-433.

31. Bucardo F, Kindberg E, Paniagua M, Grahn A, Larson G, Vildevall $\mathrm{M}$ et al. Genetic susceptibility to symptomatic norovirus infection in Nicaragua. J Med Virol 2009;81:728 $-735$

32. Nordgren J, Kindberg E, Lindgren PE, Matussek A, Svensson L. Norovirus Gastroenteritis Outbreak with a Secretorindependent Susceptibility Pattern, Sweden.Emerg Infect Dis 2010; 16:81-87 